\title{
Forming Mechanism of the Loess Landslides Triggered by Irrigation and Seasonal Freezing
}

\author{
Wenhong Liu ${ }^{1, a^{*}}$, Tonglu $\mathrm{Li}^{1, \mathrm{~b}}$ \\ ${ }^{1}$ Department of Geological Engineering, Chang'an University,Xi'an, 710054, Shaanxi, China \\ a794288735@qq.com, bdcdgx08@chd.edu.cn
}

Keywords: Loess landslide, Failure mechanism, Seasonal freezing.

Abstract. The fundamental characters and failure mechanism of the landslides related to freeze-thaw action are introduced in this paper. Monitoring of the ground temperature and the pore water pressure at the landslide located at the side of the Heifangtai loess platform, Gansu province suggested freezing can build an underground reservoir at the deep position within the slope in frozen season and then after thawing can release the water out in warmer season. Consequently, it produces a high pore water pressure in winter as well as a high water gradient in spring as the water released. Both the static high pore water pressure and the high water gradient will decrease the slope stability and trigger landslides.

\section{Introduction}

Generally speaking, rainfall is the chief reason of most landslides, but in Gansu, Qinghai provinces and some other areas of the western Loess Plateau, where is arid climate and has less precipitation, that the moisture content of natural loess is often less than $10 \%$. Therefore, many landslides occurred in freeze-thaw seasons are not merely related to the rise of groundwater table that recharged by rainfall and irrigation, but closely to seasonal freeze and thaw action. Freezing begins in October to November and thawing in the following February till March in Northern China each year. The lowest air temperature can reach to minus $20^{\circ} \mathrm{C}$ or below, and the largest frozen depth varies from 1.0 to $2.5 \mathrm{~m}$ in the area.

Seasonal freeze and thaw action includes two opposite processes of freezing and thawing, they have different mechanism and pattern on aggravating slope deformation and failure. Freezing can prevent groundwater form discharging in loess, resulting in accumulation of groundwater in slope, which is called Frozen Water Barred Effect [1,2]. The effect may cause a rise of static pore water pressure, coincidently decreasing the slope stability. Inversely, thawing may suddenly release the enclosed water as it is warming, which will produce a high water gradient and also trigger landslides. The slope stability may be improved by draining in the summer season. However, the actions repeats year by year, finally make the slope conditions worse and worse.

\section{The landslides at the side of the Heifangtai loess platform triggered by seasonal freeze-thaw action}

Here we take the landslides at the side of Heifangtai loess platform, Gansu Province, China as an example, to illustrate the forming mechanism of landslides triggered by seasonal freeze-thaw action. The Heifangtai platform is located in the town of Yanguoxia, Yongjing County, Gansu Province, situating on the left bank of the Yellow River and the convergence of the Yellow River and the Huangshui river. The platform was formed by Quaternary eolian loess deposit on the III terrace of the Yellow River. Its north boundary is a gully with the depth 30 110 m and the gradient of $13^{\circ} \sim 40^{\circ}$, the east and the south boundary is next the II terrace of the Yellow River. The slope of the platform side has the height of $60 \sim 131 \mathrm{~m}$ and the gradient of $20^{\circ} \sim 50^{\circ}$. The steep and high slope 
at the side of Heifangtai platform prefer to occurrence of landslides as shown in figure 1. The top of the platform is $1.7 \mathrm{~km}$ long east-west, $1.3 \mathrm{~km}$ wide south-north and has the total area of $13.7 \mathrm{~km}^{2}$. It used to be an arid platform without resident in the originally. However, in the early 1960s, due to construction of the Liujiaxia,Yanguoxia and Bapanshan reservoirs,people lived in the reservoirs were immigrated on the platform. For exploiting the barren land for the immigrant living, the Yellow River pumping irrigation project was begun to built since 1966. Now there has been built four villages with 848 households and 4028 people resettled on the platform. From July 1966 to June 1969, three high-lift pumping station were put into use, which has the total water supply of $2.115 \mathrm{~m}^{3} / \mathrm{s}$ for 11340 acres of farmland irrigation. Till April 2012, there are 11 trunk conduits with total length of $11.5 \mathrm{~km}$ and 48 branch ones with total length of $28.3 \mathrm{~km}$ on the platform. From 1981 to 1989 , the average annual irrigation amount was 7.22 million $\mathrm{m}^{3}, 598 \mathrm{~m}^{3}$ each acre. However, from 1990 to 1999, the average annual irrigation amount was 5.76 million $\mathrm{m}^{3}, 425 \mathrm{~m}^{3}$ each acre. In recent years, the average annual irrigation amount keeps in 5.91 million $\mathrm{m}^{3}$.

Since irrigating on the top of the platform, landslides began to occur at the side of Heifangtai platform frequently. The landslides had caused more than 400 million of economic loss and 38 causalities, injured more than 100 people, destroyed about 500 acres of farmland, cut the roads leading to Yanguoxia Chemical Plant and Yanguoxia Power Plant for several times. 3000 acres of arable land were abandoned in the margin of the platform. According to our investigation in August 2010, 37 places of landslide at the side of Heifangtai platform were confirmed. The actual number of landslide events is more than this figure because the same place may have occurred several times of failure.

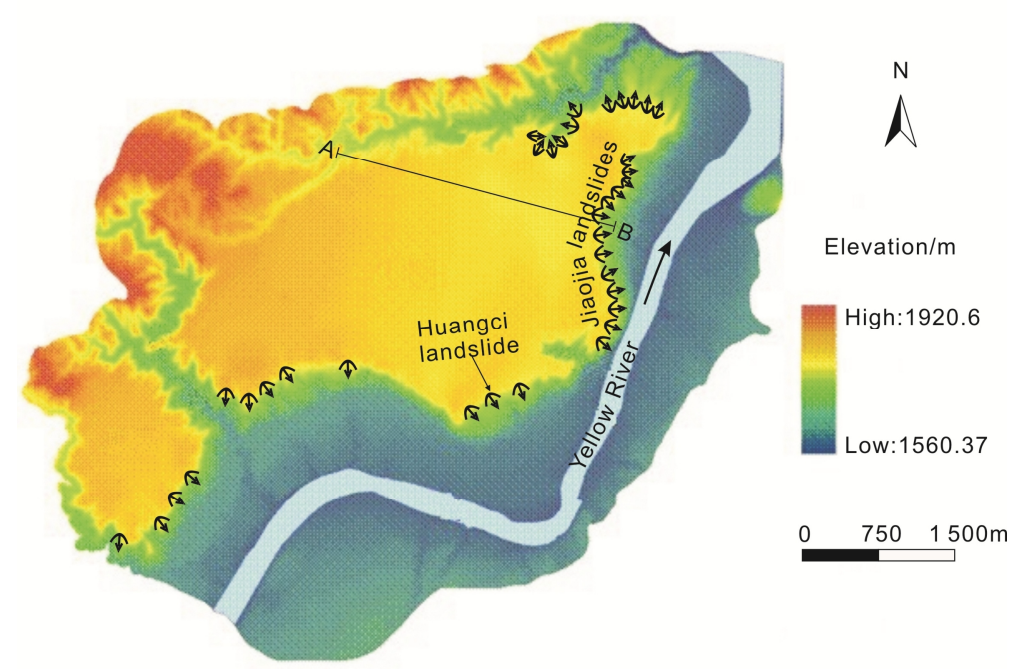

Fig.1 DEM diagram and the landslides in the Heifangtai platform

The Heifangtai platform is composed of aeolian loess deposit, alluvium of the Yellow River terrace and bedrock from top to bottom (Fig.2). Aeolian loess $\left(\mathrm{Q}_{3}{ }^{\mathrm{el}}\right)$ has grayish yellow color, loose texture and uniform structure, with macroporous, silt component and well vertical joints, it is easy to disintegrate in water. The loess bed is $21 \sim 50 \mathrm{~m}$ thick laid on the alluvium bed of the IV terrace of the Yellow River. The upper alluvium bed $\left(\mathrm{Q}_{2}{ }^{\mathrm{al}}\right)$ is of the $0.3-2.0 \mathrm{~m}$ thick of lamina light brown silty clay with horizontal bedding and interbeded with yellowish fine sand; the lower is pebbles which consists of quartzite, granite and metamorphic rocks, round to sub-round, well sorting, with the grain size of from 3 to $10 \mathrm{~cm}$, filled with silt, no cementation. It is $2 \sim 5 \mathrm{~m}$ thick outcroping along the side of the platform. The bedrock is Cretaceous interbeded sand-mudstone $\left(\mathrm{K}_{1}{ }^{\mathrm{hk}}\right)$ consisting of thick-bedded brown sandstone and fine bedded mudstone, commonly having $0.5 \sim 1.0 \mathrm{~cm}$ thick 
gypsum intercalations, with the attitude $185^{\circ} \angle 12^{\circ}$. The bedrock outcrops about $70 \mathrm{~m}$ thick on the lower of the side slopes.

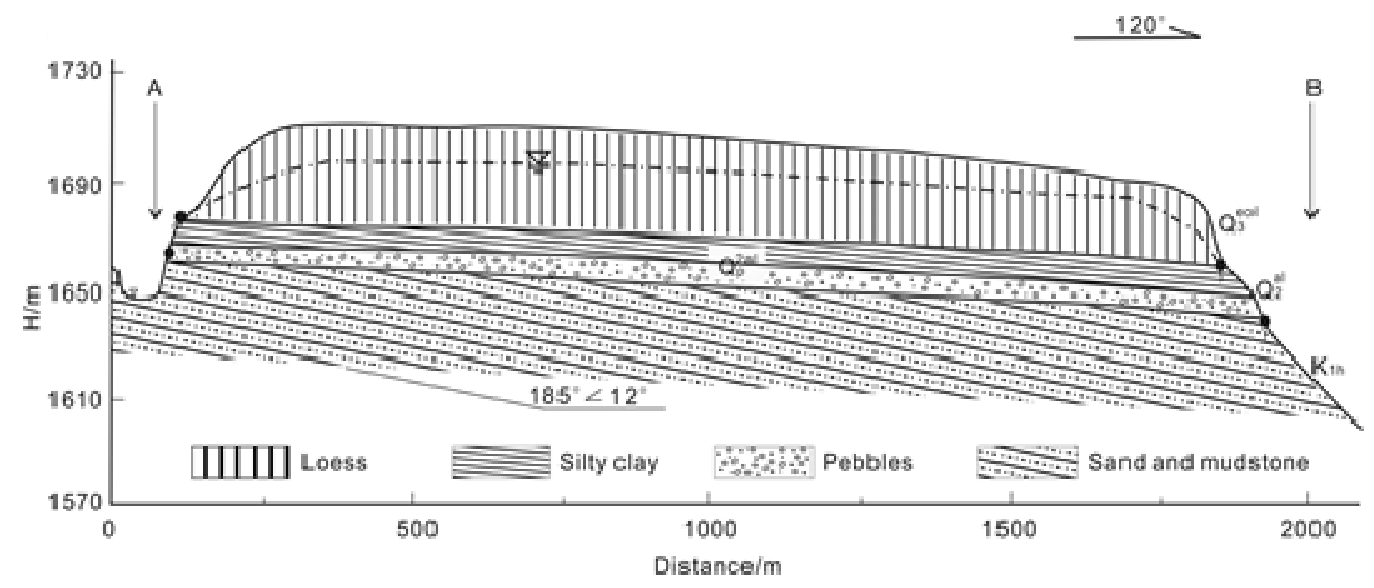

Fig. 2 Geological profile of the Heifangtai platform (The line AB in figure 1)

The hydrogeological condition was entirely changed by the long-term and massive irrigation. Perched water table was formed in the loess bed over the whole area. Before irrigation, phreatic water was distributed discontinuously. The bedrock base dips from the west to east in the platform, so the west almost had no groundwater before, and the east only had a very thin groundwater. Since the extensive irrigation started in 1968, perched water table was formed on the relative impermeable alluvial silty clay and the water level increases at the rate of $0.27 \mathrm{~m}$ each year. The water level at the center of the platform has rose by $20 \mathrm{~m}$ high. Figure 3 shows that on the upper of the side slope, groundwater has been leaking along the top of the silty clay bed. Undoubtedly, continuous rising of the groundwater level with irrigation was the main cause of landslides at the side of Heifangtai platform. However, the landslides occurred at the side of Heifangtai platform with clear time records suggests that March and July are two peak numbers[3]. The peak in July is closely related to an irrigation in May, while the peak in March was apparently related to freeze-thaw action.

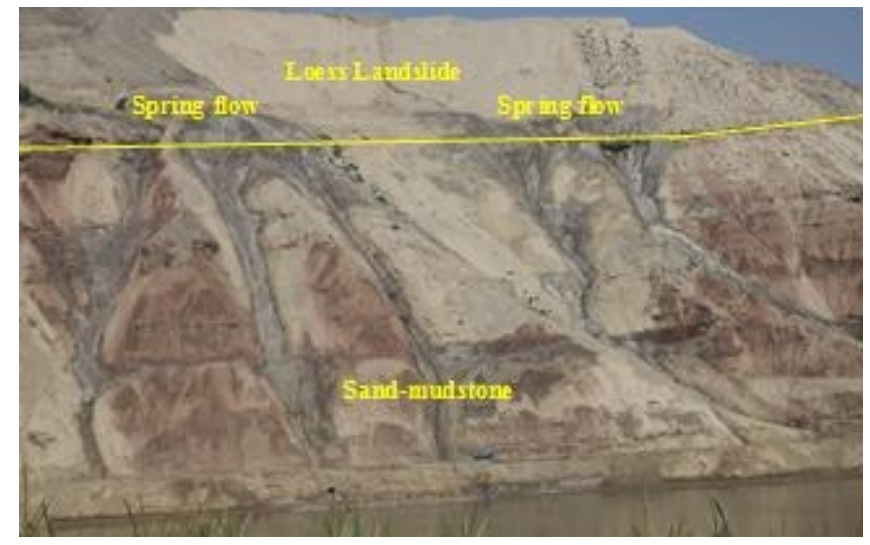

Fig.3 Groundwater flow along the top of silty clay on the upper slope

\section{The mechanism of the landslide triggered by seasonal freeze-thaw action}

Loess landslides occurred in the loess layer lying on the alluvial silty clay. A thick perched water was generated on the top of alluvial clay because of relative impermeability. Heifangtai platform tilts from south-west to north-east, groundwater flows to north-east and spills along the top of the silty clay on the northeast side of the platform near Jiaojia village, so a series of landslides were triggered and distributes side-by-side as shown in figure 4. The earliest case occurred on 
March $15^{\text {th }}, 1989$, which is located to the south of Jiaojia village and next to the bank of the Yellow River. There were 60 thousand $\mathrm{m}^{3}$ sliding mass slipped into the Yellow River, the water was flooded on to the opposite bank and inundated 1.6 acres farmland. Another loess landslide with the volume of 400 thousand $\mathrm{m}^{3}$ was occurred along the slope behind the Silicon-Carbide Factory to south of Jiaojia village on March $12^{\text {th }}, 1999$, sliding mass proceeded $500 \mathrm{~m}$ in 30 seconds. In recent years, landslides often occurred in this area. A length of only $3 \mathrm{~km}$ slope of platform has 15 loess landslides occurred. Loess landslides show the characters of high shear outlet and quick sliding speed. The height of the shear outlet relative to the toe of the slope is 60 to $80 \mathrm{~m}$. As the landslide started to slip, the loose saturated loess in the base changed from solid to fluid rapidly, then flowed down on the slope. Is belongs to rapid flow slide. Figure 5 shows the geological section of Jiaojia loess landslide.

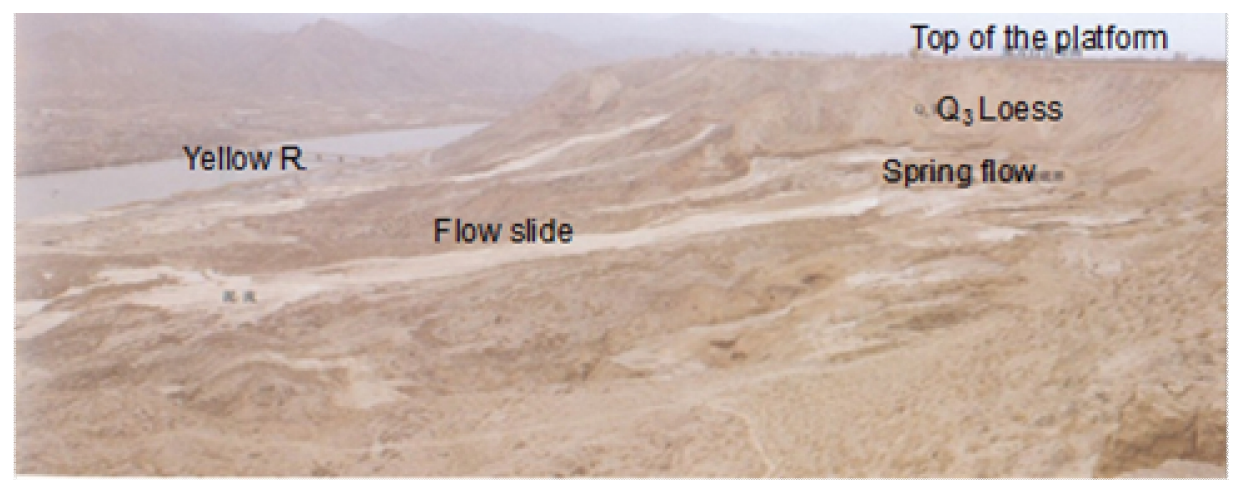

Fig.4 Jiaojia Landslide group (The location seeing figure1)

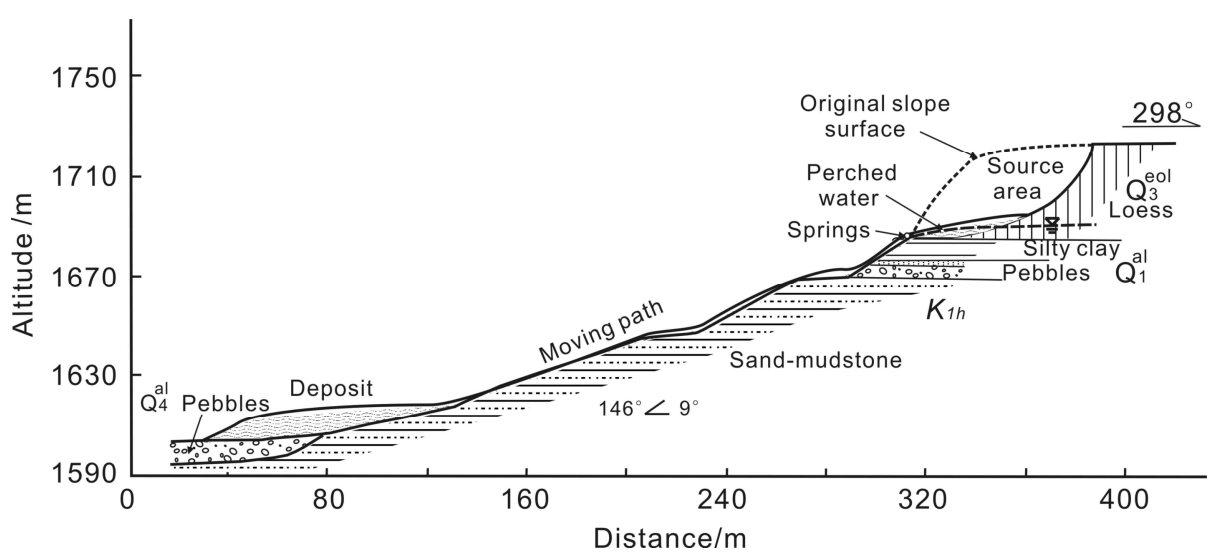

Fig.5 Geological section of Jiajia loess landslide

From more than 30-years record of the landslides on the side of Heifangtai platform, it is found that the landslides occurred at the winter and the early spring were more than those in the other seasons. However, it is not the irrigation time, so the reason might attribute to freeze-thaw action. In order to obtain the data of ground temperature and pore water pressure, monitoring devices were buried in the front of a largest landslide in Jiaojia village by Xi'an Geological Survey Center. Fig.6 shows the data of ground temperature at the depth of $10 \mathrm{~cm}$ and pore water pressure at the depth of $3 \mathrm{~m}$ in the period from December $9^{\text {th }}, 2010$ to May $26^{\text {th }}, 2011$. From the results, The freeze-thaw process can be divided into three episodes, namely freezing, freezing-thawing and thawing. Freezing episode began at the end of November and ended in the beginning of the next February, the ground temperature was below $0^{\circ} \mathrm{C}$. Therefore, the groundwater drainage paths were closed, which resulted in a continuous rising of pore water pressure in the slope. Freezing-thawing period started in the early February and ended in the early March. Temperature fluctuated between day and night, which may resulted in alternative freezing and thawing between day and night, but the 
groundwater drainage paths were still blocked, so pore water pressure still increased steadily. The thawing period started from the early March to the end of April, spring water began to discharge as normal, and the pore water pressure does not rise any more, but had a tendency of decrease with some sudden falls.

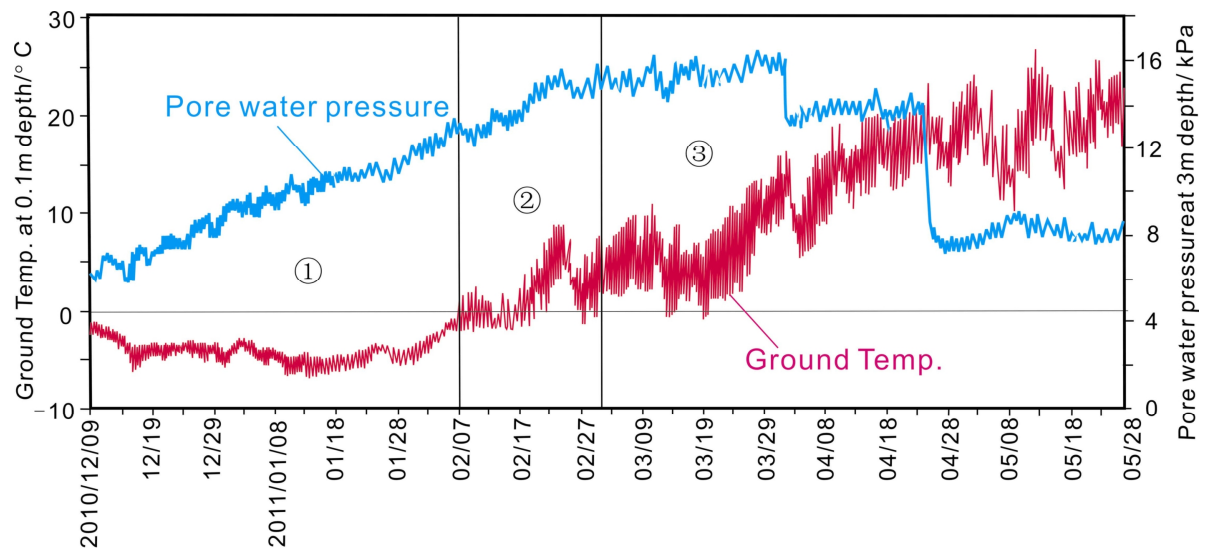

Fig.6 Pore water pressure and ground temperature variation with time in JH9 landslide

The above monitoring results show that groundwater level in the slope could increase because the frozen water closed the water drainage outlet. The range of water lifting on the slope could be 2 $\mathrm{m}$ by once frozen season, then it is estimated that the affected horizontal distance might be more than $30 \mathrm{~m}$ according to the loess permeability. The rise of groundwater level could lead to the rise of static pore water pressure and reduce soil strength. For investigating the loess strength under increasing of pore water pressure, intact loess samples near shear outlet the monitored landslide were taken. The specimens were saturated in laboratory and consolidated under definite confining pressure and axial pressure, and then pore water pressure was increased by exerting counter pressure to make the specimen fail. The results are expressed as stress path as in figure 7 . Effective cohesion and internal friction angle may be calculated through parameters of $K_{f}$ line. The effective cohesion was near to 0 and the internal friction angle was $30.1^{\circ}$. Gradients of the loess slopes at the side of Heifangtai platform were generally $30^{\circ}-35^{\circ}$. It may be concluded that increase of groundwater level and pore water pressure by freezing caused that loess cohesion almost lost and the effective internal friction angle is even below the slope gradient, so the slope failure could be occurred naturally.

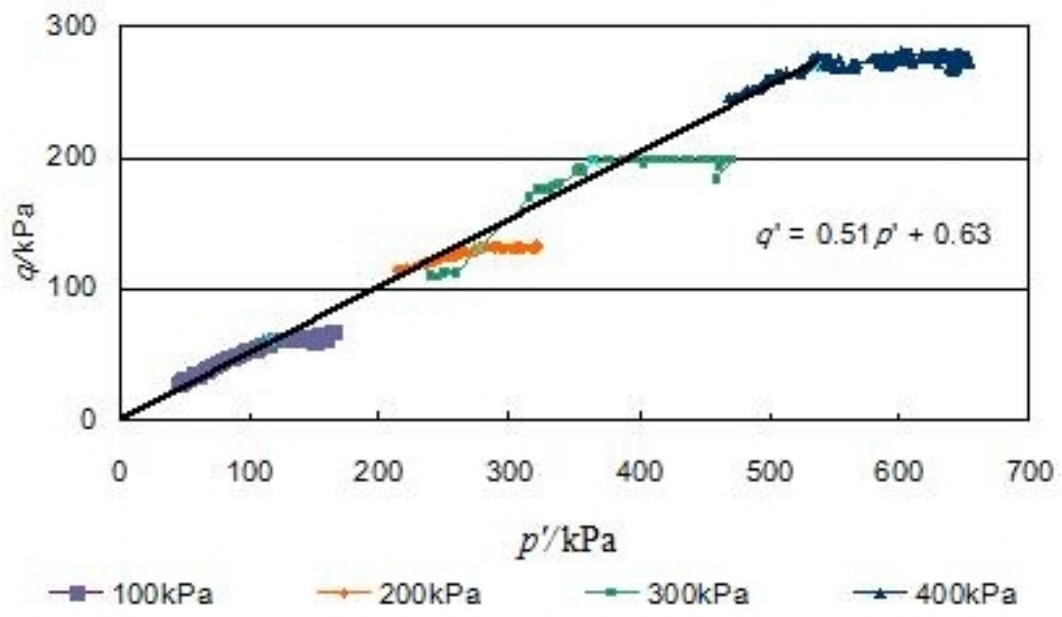

Fig.7 Stress path of triaxial CU shear test under the conditions of giving confining axial pressure and by increasing pore water pressure

Once the landslide occurred, loess in the disturbed shear zone converted into flow state 
immediately because of its loose structure, and then rapid mud flow along the slope surface was generated. It can be measured that loess moisture content is greater than its liquid limit. Even during the thawing period, high hydraulic gradient would be generated due to the sudden release of groundwater, which was also unfavorable to slope stability.

\section{Conclusions}

There is a high incidence of landslides in freeze-thaw seasons in the loess region of the Northwestern China, seasonal freeze-thaw effect is a dominant exterior factor for triggering this type landslides. Landslides on the side of Heifangtai platform, Gansu province, are the most typical cases triggering by freeze-thaw action. According to investigation, monitoring and triaxial test for the landslide in this area, it can be concluded that groundwater discharge outlet was barred by freezing action, which resulted in accumulation of groundwater within the slope, then increased pore water pressure and reduced soil strength consequently caused the slope failure. High hydraulic gradient may be generated by the sudden release of groundwater due to thawing, slope stability also can be reduced and fail eventually.

\section{Acknowledgement}

This research was funded by one of National Basic Research Program of China (2014CB744701) and National Natural Sicence Fundation of China (Program No.41372329).

\section{References}

[1] Wu Weijiang, Seasonal freeze-thaw action and the entire deformation failure of slope, The Chinese Journal of Geological Hazard and Control, 1996, 7(4):59-64(In Chinese).

[2] Wu Weijiang, Slide accelerated by water entrapment due to seasonal freezing, Journal of glaciology and geocryology, 1997, 19(4):359-365(In Chinese).

[3] Wang Nianqin, Yao Yong, Characteristics and mechanism of landslides in loess during freezing and thawing periods in seasonally frozen ground Regions, Journal of Disaster Prevention and Mitigation Engineering 2008, 28(2):163-166. 